\title{
Pengaruh Model Pembelajaran Giving Question Getting Answer dan Think Pair Share terhadap Kemampuan Penalaran Matematika Siswa Kelas VII
}

\author{
Asurya Octaviyunas ${ }^{1}$ dan Arta Ekayanti ${ }^{2 *}$ \\ 1,2*Program Studi Pendidikan Matematika, Universitas Muhammadiyah Ponorogo \\ Jalan Budi Utomo No. 10, Ponorogo, Jawa Timur, Indonesia \\ 1aiya9293@gmail.com, 2*arta_ekayanti@ymail.com
}

Artikel diterima: 20-02-2019, direvisi: 31-05-2019, diterbitkan: 31-05-2019

\begin{abstract}
Abstrak
Penelitian ini didasari atas permasalahan pentingnya kemampuan penalaran matematis dan pencapaiannya yang masih rendah. Tujuan dari penelitian ini adalah mengetahui pengaruh model pembelajaran Giving Question Getting Answer dan Think Pair Share terhadap kemampuan penalaran matematika siswa, dan efektifitasnya dalam meningkatkan kemampuan tersebut. Populasi Penelitian eksperimen semu ini mencakup seluruh siswa kelas VII SMPN 1 Balong. Kelas VIIA diberi pembelajaran dengan model TPS sedangkan kelas VIIB dengan model GQGA. Instrumen pengumpulan data berbentuk tes, meliputi soal pretest dan posttest. Hasil penelitian menunjukkan bahwa model pembelajaran GQGA berpengaruh terhadap kemampuan penalaran siswa kelas VIIB dengan peningkatan yang terjadi dari nilai pretest ke posttest. Begitu juga dengan model pembelajaran TPS berpengaruh terhadap kemampuan penalaran matematika siswa kelas VIIA dengan peningkatan nilai pretest ke posttest. Model pembelajaran GQGA tidak lebih efektif daripada model pembelajaran TPS dalam meningkatkan kemampuan penalaran matematika siswa.

Kata Kunci: Model Pembelajaran, GQGA, TPS, Kemampuan Penalaran Matematika.
\end{abstract}

\section{The Effect of Learning Model Giving Question Getting Answer and Think Pair Share Toward Reasoning Mathematics Ability Student's Grade VII}

\begin{abstract}
This research is based on the problem of the importance of mathematical reasoning abilities and their low achievement. The purpose of this study was to determine the effect of Giving Question Getting Answer and Think Pair Share learning models on students' mathematical reasoning abilities and their effectiveness in enhancing these abilities. Population This quasi-experimental study included all seventh-grade students of Balong 1 Junior High School. The VIIA class is given learning with the TPS model while the VIIB class is with the GQGA model. The instruments of data collection are in the form of tests, including the questions of the pretest and posttest. The results showed that the GQGA learning model had an effect on the reasoning ability of students in class VIIB with an increase that occurred from the pretest to the posttest. Likewise, the TPS learning model influences the mathematical reasoning abilities of VIIA students with an increase in the value of the pretest to posttest. The GQGA learning model is no more effective than the TPS learning model in improving students' mathematical reasoning abilities.

Keywords: Learning Model, GQGA, TPS, mathematical reasoning abilities.
\end{abstract}




\section{Pendahuluan}

Pendidikan merupakan kebutuhan penting dalam kehidupan manusia. Pendidikan adalah aspek yang perlu diperhatikan dalam proses pengembangan diri manusia. Sebuah Hadist mengatakan "Menuntut ilmu itu wajib atas setiap muslim"(HR. Ibnu Majah no. 224) dan "Kejarlah ilmu sampai ke negeri Cina". Demikian pentingnya pendidikan dan sangat dianjurkan dalam agama. Dalam mencapai tujuan pendidikan, perlu diadakannya proses pembelajaran salah satunya pembelajaran matematika. Depdiknas menyebutkan bahwa untuk menguasai serta menciptakan teknologi pada masa yang akan datang diperlukan penguasaan kompetensi matematika yang mantap sejak dini (Depdiknas, 2006).

Untuk dapat menguasai matematika diperlukan penalaran atau aktifitas berfikir dari peserta didik. Penalaran matematika pun menjadi salah satu aspek penting agar tujuan pembelajaran matematika tercapai. Penalaran juga berperan penting dalam proses berpikir secara kreatif, logis, dan sistematis, sehingga peserta didik dapat menyimpulkan penyelesaian beberapa fakta yang diketahui dengan baik. Menurut Suria sumantri penalaran merupakan proses berpikir dalam pengambilan kesimpulan yaitu berupa pengetahuan (Syartika, 2016).

Penalaran merupakan suatu bentuk pemikiran, Hardjosatoto menyatakan bahwa penalaran menjadi salah satu kejadian dari proses berpikir (Ahmad,
2015). "Mathematical reasoning is reasoning about and with the object of mathematic"s oleh Brodie (Syartika, 2016). Artinya, penalaran matematika adalah penalaran yang mengenai dan dengan objek matematika. Kemampuan penalaran matematika membantu peserta didik dalam menyimpulkan dan membuktikan suatu pernyataan, membangun gagasan baru, sampai pada penyelesaian masalah matematika. Disamping itu, penalaran matematika juga digunakan untuk menentukan kebenaran dari suatu argumen matematika serta dapat digunakan untuk membentuk argumen matematika tertentu (Siregar, 2016). Anjar dan Sembiring mengatakan bahwa seseorang dikatakan melakukan penalaran matematika jika dia dapat melakukan validasi, membuat konjektur, deduksi, justifikasi, dan eksplorasi (Nurmanita \& Surya, 2017).

Berdasarkan hasil wawancara dengan guru matematika SMP Negeri 1 Balong, diketahui bahwa peserta didik masih cenderung menggunakan model menghafal dalam pembelajaran matematika, terutama peserta didik kelas VII. Guru menyampaikan bahwa peserta didik masih kesulitan dalam mengaplikasikan pengetahuan yang diperoleh sebelumnya untuk digunakan pada pengetahuan baru yang diterimanya. Selain itu proses menalar peserta didik juga masih belum terlihat. Hal tersebut diungkapkan guru ketika beliau memberikan soal-soal atau tugas yang memerlukan proses bernalar peserta didik. 
Peserta didik cenderung hanya diterapkan dengan membentuk kelompok menggunakan rumus yang peserta didik ketahui ketika membaca soal.

Kurang bervariasinya cara mengajar pendidik saat ini menjadi salah satu sebab peserta didik kurang bersemangat dalam mengikuti pembelajaran di kelas. Peserta didik cenderung hanya menerima ilmu yang disampaikan oleh bapak ibu guru secara mentah-mentah tanpa adanya kelola dari peserta didik itu sendiri. Peserta didik cenderung kurang dalam menggunakan kemampuan berpikirnya untuk menyelesaikan suatu permasalahan matematika. Dalam penelitian ini akan diterapkan model pembelajaran kooperatif yang dapat membantu peserta didik dalam melatih aktifitas berpikir untuk menunjang kemampuan bernalarnya dalam pembelajaran matematika

Banyak sekali model pembelajaran kooperatif yang dapat diterapkan dalam pembelajaran, diantaranya adalah model pembelajaran Giving Question Getting Answer (GQGA) dan Think Pair Share (TPS). Model GQGA dapat melatih peserta didik dalam melakukan kegiatan bertanya dan menjawab pertanyaan (Suprijono, 2009). Dalam membuat dan menjawab pertanyaan diperlukan aktifitas kognitif yang baik dan terkoneksi pada pembelajaran yang dilaksanakan. Secara langsung peserta didik akan terus berfikir dan menggunakan penalarannya dalam mengemukakan dan menjawab pertanyaan. Untuk mendapatkan hasil yang optimal Model GQGA dapat

Mosharafa: Jurnal Pendidikan Matematika

Volume 7, Nomor 3, September 2018

Copyright @ 2019 Mosharafa: Jurnal Pendidikan Matematika yang heterogen (Aisyah \& Sofyan, 2014).

Model pembelajaran GQGA merupakan modifikasi dari metode ceramah dan metode tanya jawab yang dikolaborasikan dengan menggunakan media potonganpotongan kertas (Suprijono, 2009). Model pembelajaran GQGA cukup baik digunakan untuk melatih proses memunculkan pertanyaan dan menjawab dari peserta didik dengan melibatkan kemampuan berpikirnya. Dewi Chosiyah pada tahun 2013 telah melakukan penelitian yang menunjukkan bahwa Model Pembelajaran GQGA meningkatkan hasil belajar siswa. Dalam penelitian ini akan dispesifikkan terkait hasil belajar yaitu fokus pada kemampuan penalaran matematika.

Model Pembelajaran TPS merupakan jenis pembelajaran kooperatif yang dirancang untuk mempengaruhi pola interaksi siswa (Sari, 2013). Model pembelajaran ini memberi kesempatan peserta didik dalam mengembangkan kemampuan berfikirnya secara individu kemudian saling bertukar pikiran dengan teman lainnya (Nasution \& Surya, 2017). Selanjutnya, semua peserta didik memiliki jawaban dari dirinya masing-masing dan mampu memahami bahwa jawaban dari masalah itu beragam caranya.

Nataliasari (2014) menyatakan bahwa TPS merupakan model pembelajaran kooperatif yang memberikan kesempatan kepada peserta didik untuk memberikan partisipasinya kepada orang lain. Nasution \& Surya (2017) menyatakan "The Think Pair Share strategy is designed to 343 
differentiate instruction by providing students time and structure for thinking on a given worksheets enabling them to formulate individualized reviews these ideas and share ideas with a partner". Artinya TPS dirancang sebagai model pembelajaran yang menyediakan waktu bagi siswa untuk memikirkan jawaban dari masalah yang diberikan secara individual dan kemudian bertukar pikiran dengan pasangannya. Ike Nataliasari Sari telah melakukan penelitian pada tahun 2014 yang menunjukkan bahwa Model Pembelajaran TPS meningkatkan kemapuan penalaran matematika. Dalam hal ini, penelitian ini akan fokus pada siswa kelas VII SMP Negeri 1 Balong.

Berdasar uraian diatas, penelitian ini bertujuan untuk mengetahui pengaruh dari penerapan model pembelajaran GQGA dan TPS pada masing-masing kelas eksperimen yang ditentukan terhadap kemampuan penalaran matematika siswa kelas VII SMP N 1 Balong. Hal ini dilakukan mengingat sejauh ini belum ada penelitian yang melihat perbandingan pengaruh dari dua model pembelajaran tersebut terhadap kemampuan penalaran matematika.

\section{Metode}

Jenis penelitian ini berupa penelitian kuantitatif eksperimen. Metode yang digunakan adalah Quasi Experimental Design (eksperimen semu). Eksperimen sejati merupakan penelitian dengan menetapkan secara acak kelompok yang akan diteliti (Creswell, 2012). Penelitian ini tidak memiliki kelompok kontrol. Kelompok yang digunakan pada penelitian ini adalah dua kelompok eksperimen yaitu kelas eksperimen 1 dan kelas eksperimen 2 dimana kelas eksperimen 1 diberikan perlakuan dengan menerapkan model pembelajaran GQGA dan kelas eksperimen 2 dengan model pembelajaran TPS. Dalam penelitian ini akan digunakan desain penelitian dengan Pretest And Posttest Design (Creswell, 2012).

Populasi adalah sekelompok individu yang memiliki kesamaan karakteristik tertentu dan ditetapkan oleh peneliti untuk diidentifikasi dan dipelajari. Sedangkan sampel merupakan sebagian dari populasi yang diambil oleh peneliti untuk selanjutnya dipelajari sehingga diperoleh suatu kesimpulan (Creswell, 2012) (lihat tabel 1).

Pengambilan sampel pada penelitian ini menggunakan simple random sampling. Artinya, setiap sampel yang dipilih memiliki probabilitas yang sama untuk dipilih dari populasi yang ada (Creswell, 2012). Semua sampel diajar oleh pengajar yang sama dengan materi yang sama dan kapasitas waktu pembelajaran yang sama. Populasi pada penelitian ini yaitu semua siswa dari enam kelas VII SMP Negeri 1

Tabel 1.

Desain Penelitian Pretest dan Posttest

\begin{tabular}{cccc}
\hline $\begin{array}{c}\text { Kelompok } \\
\text { eksperimen }\end{array}$ & Pretest & Perlakuan & Posttest \\
1 & & & \\
\hline $\begin{array}{c}\text { Kelompok } \\
\text { eksperimen }\end{array}$ & Pretest & Perlakuan & Posttest \\
2 & & & \\
& & & \\
& & &
\end{tabular}

Mosharafa: Jurnal Pendidikan Matematika Volume 7, Nomor 3, September 2018 Copyright $\odot 2019$ Mosharafa: Jurnal Pendidikan Matematika 
Balong dan sebagai sampel adalah kelas VIIA dan kelas VIIB.

Adapun teknik pengumpulan data penelitian ini yaitu metode tes. Tes adalah suatu alat atau prosedur yang sistematis dan objektif untuk memperoleh data yang diinginkan dalam penelitian (Arikunto, 1995). Pada penelitian ini akan dilakukan tes penalaran matematika yang berupa pretest dan posttest. Tes yang diberikan merupakan tes tertulis dengan soal uraian. Pretest digunakan untuk mengetahui kemampuan awal dan posttest untuk mengetahui hasil akhir setelah perlakuan yang diberikan kepada kedua kelompok eksperimen. Soal tes diberikan secara individu kepada peserta didik.

Sebelum instrumen dapat digunakan pada penelitian, perlu dilakukannya pengujian validitas instrumen tersebut. Pada penelitian ini validitas yang digunakan adalah validitas logis. Validitas logis merupakan validitas yang dinyatakan berdasar hasil penalaran dan dirancang dengan baik sesuai teori dan ketentuan yang ada dan instrumen tidak perlu diuji coba terlebih dahulu (Jainuri, n.d.). Terdapat dua macam validitas logis yaitu validitas isi dan validasi konstruk. Validitas yang digunakan dalam penelitian ini adalah validitas isi. Adapun validitas isi adalah validitas yang dilakukan dengan pengujian kelayakan serta relevansi dari isi tes yaitu melalui analisis rasional oleh ahli atau dengan penilaian ahli, sehingga diperlukan validator ahli yang memiliki keahlian dalam menilai, memperbaiki, memberi saran, menimbang isi dan memahami materi dari instrumen yang digunakan dalam penelitian.

Menurut Sudijono validator yang dipilih yaitu para pakar yang dianggap berkompetensi pada mata pelajaran terkait, yang selanjutnya dilihat bagaimana pendapat serta rekomendasinya terkait materi (Wuryani, 2017). Pada penelitian ini dipilih 2 validator ahli yaitu dosen matematika Universitas Muhammadiyah Ponorogo dan guru matematika SMP Negeri 1 Balong. Instrumen tes divalidasikan pada dua ahli validator. Aspek yang dinilai pada instrumen soal tes yaitu materi, konstruksi, dan bahasa.

Pada penelitian ini digunakan teknik analisis data yang meliputi analisis data tahap awal dan tahap akhir. Pada analisis data tahap awal, data yang dianalisis adalah hasil dari pretest pada kedua kelas eksperimen, mencakup uji normalitas, uji homogenitas, dan uji kesamaan rata-rata. Sedangkan, pada analisis data tahap akhir akan dianalisis data hasil posttest atau rentang antara posttest dan pretest kedua kelompok eksperimen. Selanjutnya, nilai posttest akan digunakan jika pada uji kesamaan rata-rata antara dua kelompok eksperimen sama dan menggunakan data rentang nilai posttest dan nilai pretest jika pada uji kesamaan rata-rata antara dua kelompok eksperimen hasilnya ada perbedaan rata-rata. Kemudian analisis data tahap akhir digunakan untuk mengetahui hasil yang diharapkan sesuai dengan hipotesis atau tidak. Analisis pada tahap ini hampir sama dengan analisis pada tahap awal yaitu meliputi uji 
normalitas, uji homogenitas, dan terakhir adalah uji hipotesis.

\section{Hasil dan Pembahasan}

Penelitian ini dilakukan untuk mengetahui pengaruh dari dua model pembelajaran yaitu GQGA dan TPS terhadap kemampuan penalaran matematika peserta didik. Selain untuk mengetahui pengaruhnya, dua model ini akan dibandingkan mana yang lebih efektif pengaruhnya terhadap kemampuan penalaran matematika. Penelitian dilaksanakan di SMP Negeri 1 Balong dengan mengambil 2 kelas eksperimen, yaitu kelas VIIB dengan peserta didik yang berjumlah sebanyak 30 sebagai kelas eksperimen 1 dan kelas VIIA dengan jumlah peserta didik sebanyak 30 sebagai kelas eksperimen 2. Kelas eksperimen 1 diberikan model pembelajaran GQGA sedangkan kelas eksperimen 2 diberikan model pembelajaran TPS.

Hasil analisis deskriptif data hasil

Tabel 2.

Hasil Analisis Deskriptif Pretest dan Posttest

\begin{tabular}{|c|c|c|c|c|}
\hline \multirow[t]{2}{*}{ Deskripsi } & \multicolumn{2}{|c|}{ Model GQGA } & \multicolumn{2}{|c|}{ Model TPS } \\
\hline & $\begin{array}{l}\text { Pre } \\
\text { test }\end{array}$ & $\begin{array}{c}\text { Pos } \\
t \\
\text { test }\end{array}$ & $\begin{array}{l}\text { Pre } \\
\text { test }\end{array}$ & $\begin{array}{l}\text { Post } \\
\text { test }\end{array}$ \\
\hline $\begin{array}{l}\text { Jumlah } \\
\text { Peserta Didik }\end{array}$ & \multicolumn{2}{|c|}{30} & \multicolumn{2}{|c|}{30} \\
\hline Rata-rata & 20.9 & 63.13 & 27.56 & 75.40 \\
\hline Median & 19 & 66 & 27 & 80 \\
\hline Modus & 25 & 66 & 15 & 80 \\
\hline $\begin{array}{l}\text { Standar } \\
\text { Deviasi }\end{array}$ & 8.13 & 14.93 & 7.65 & 18.06 \\
\hline $\begin{array}{l}\text { Nilai } \\
\text { Maksimum }\end{array}$ & 36 & 86 & 40 & 96 \\
\hline $\begin{array}{l}\text { Nilai } \\
\text { Minimum }\end{array}$ & 10 & 26 & 15 & 30 \\
\hline
\end{tabular}

pretest dan posttest pada kedua kelas eksperimen disajikan pada tabel 2.

Selanjutnya, analisis data awal memberikan hasil bahwa nilai pretest pada kedua kelas eksperimen menunjukkan adanya perbedaan rata-rata. Analisis ini menggunakanuji kesamaan rata-rata yaitu uji-t sampel bebas dengan tingkat signifikansi $(\alpha)=0.05$. Keputusan ujinya adalah jika $\left|t_{\text {hit }}\right| \geq t_{\text {tabel }}$ maka $H_{0}$ ditolak.

Hasil uji t kesamaan rata-rata disajikan pada tabel 3.

Hasil perhitungan dari uji kesamaan rata-rata adalah $t_{\text {hit }}=-3.245$ sedangkan $t_{\text {tabel }}=2.001$ dengan derajat kebebasan kedua kelas $=58$ dan $\alpha=0.05$. Diperoleh $\left|t_{\text {hit }}\right|>t_{\text {tabel }}(3.245>2.001)$, artinya $H_{0}$ ditolak sehingga terdapat perbedaan rata-rata kemampuan penalaran matematika awal antara dua kelas eksperimen atau kemampuan penalaran matematika kedua kelas tidak sama.

Untuk analisis data tahap akhir pada penelitian ini, akan dilakukan 3 uji hipotesis. Hipotesis pertama:

$H_{0}$ : model pembelajaran GQGA tidak berpengaruh terhadap kemampuan penalaran matematik peserta didik.

$H_{1}$ : model pembelajaran GQGA berpengaruh terhadap kemampuan penalaran matematik

Tabel 3.

Uji Kesamaan Rata-rata Data Pretest

\begin{tabular}{lcccc|}
\hline Kelas & $\begin{array}{c}\text { Jumlah } \\
\text { sampel }\end{array}$ & $\sum \boldsymbol{x}_{\boldsymbol{i}}$ & $\sum \boldsymbol{x}_{\boldsymbol{i}}^{\mathbf{2}}$ & $\begin{array}{c}\text { Rata- } \\
\text { rata }\end{array}$ \\
\hline GQGA & 30 & 628 & 15064 & 20.93 \\
\hline TPS & 30 & 827 & 24493 & 27.56
\end{tabular}

Mosharafa: Jumal Pendidikan Matematika Volume 7, Nomor 3, September 2018 Copyright $\odot 2019$ Mosharafa: Jurnal Pendidikan Matematika 
peserta didik.

Hipotesis kedua:

$H_{0}$ : model pembelajaran TPS tidak berpengaruh terhadap kemampuan penalaran matematik peserta didik.

$H_{1}$ : model pembelajaran TPS berpengaruh terhadap kemampuan penalaran matematik peserta didik

Hipotesis ketiga:

$H_{0}$ : model pembelajaran GQGA tidak lebih efektif dari model pembelajaran TPS dalam meningkatkan kemampuan penalaran matematik peserta didik.

$H_{1}$ : model pembelajaran GQGA lebih efektif dari model pembelajaran TPS dalam meningkatkan kemampuan penalaran matematik peserta didik

Pada hipotesis pertama digunakan uji t untuk sampel berpasangan. Data yang digunakan adalah hasil dari pretest dan posttest kelas GQGA yang telah memenuhi syarat mempunyai distribusi normal serta homogen.

Berikut hasil uji t sampel berpasangan kelas GQGA

$t=\frac{\bar{D}}{\frac{s_{\bar{D}}}{\sqrt{n}}} \quad$ (Djudin, 2013:18)

$t=\frac{42.2}{2.30}=18.35$

Keterangan:

$\bar{D}=$ rata-rata selisih (beda) nilai pretest dan posttest
$S_{\bar{D}}=$ simpangan baku dari selisih nilai pretest dan posttest

$n=$ jumlah sampel

Untuk $t_{\text {tabel }}$

$t_{\text {tabel }}=t_{\alpha(n-1)}$

$t_{\text {tabel }}=t_{0.05(29)}$ atau $t_{0.01(29)}$

$t_{\text {tabel }}=2.045$ atau 2.756

Hasil perhitungan uji Paired Sample tTest pada kelas model GQGA dengan jumlah siswa 30 diperoleht $_{\text {hitung }}=18.35$. $t_{\text {hitung }}$ kemudian dibandingkan $t_{\text {tabel }}$ dengan $d k=n-1=30-1=29$, taraf signifikansi $\quad \alpha=0.01$ diperoleht $t_{\text {tabel }}=2,756$. Dengan uji dua pihak diperoleh, $t_{\text {hitung }}>t_{\text {tabel }}(18.35>$ $2,756)$. Karena $t_{\text {hitung }}=18.35$ terletak di luar interval daerah penerimaan $H_{0}$, artinya $H_{0}$ ditolak yang berarti model pembelajaran GQGA berpengaruh terhadap kemampuan penalaran matematika peserta didik.

Selama proses pembelajaran di kelas GQGA, peserta didik sangat aktif dalam mengikuti kegiatan pembelajaran. Peneliti pada saat pembelajaran dapat melanjutkan materi dari hasil pertanyaan yang muncul dari peserta didik, sehingga peserta didik ikut terlibat dalam proses pembelajaran. Dengan model berkelompok lebih memudahkan peserta didik untuk mengemukakan pendapat dan menuangkan hasil pemikirannya secara percaya diri. Peserta didik juga lebih berani untuk mengajukan pertanyaan bersama dengan kelompoknya dibanding bertanya secara individu. Peserta didik juga dapat menyimpulkan hasil jawaban pertanyaan 
yang telah ditanyakan oleh peserta didik lain menggunakan pemikiran sendiri tanpa terpaku dengan teks yang ada. Secara garis besar, peserta didik telah mampu melibatkan kemampuan pemikiran dan penalarannya dengan memunculkan pertanyaan tentang masalah dan jawaban dari masalah yang diberikan meskipun perlu adanya bantuan dari pendidik. Hal ini sejalan dengan penelitian yang dilakukan oleh Dewi Chosiyah tahun 2013 dengan judul Pengaruh Pembelajaran Model Pembelajaran Kooperatif Tipe Giving Question and Getting Answer (GQGA) terhadap Hasil dan Minat Belajar Matematika Siswa Kelas VII SMP Negeri 3 Singingi Hilir Kab. Kuantan Singingi.

Hipotesis kedua uji yang digunakan masih sama dengan hipotesis pertama yaitu uji t untuk sampel berpasangan. Data yang digunakan adalah hasil dari pretest dan posttest kelas TPS yang telah memenuhi syarat berdistribusi normal dan homogen.

Berikut perhitungan uji $t$ sampel berpasangan kelas TPS

$t=\frac{\bar{D}}{\frac{s_{\bar{D}}}{\sqrt{n}}}$

$t=\frac{47.83}{2.65}=18.05$

Keterangan:

$\bar{D}=$ rata-rata selisih (beda) nilai pretest dan posttest

$S_{\bar{D}}=$ simpangan baku dari selisih nilai pretest dan posttest

$n=$ jumlah sampel
Untuk $t_{\text {tabel }}$

$t_{\text {tabel }}=t_{\alpha(n-1)}$

$t_{\text {tabel }}=t_{0.05(29)}$ atau $t_{0.01(29)}$

$t_{\text {tabel }}=2.045$ atau 2.756

Hasil perhitungan uji Paired Sample tTest pada kelas model TPS dengan jumlah siswa $30 \quad$ diperoleht $_{\text {hitung }}=18,05$. $t_{\text {hitung }}$ kemudian dibandingkan $t_{\text {tabel }}$ dengand $k=n-1=30-1=29$, taraf signifikansi $\alpha=0.01$ diperoleh $t_{\text {tabel }}=2,756$. Dengan uji dua pihak diperoleh, $t_{\text {hitung }}>t_{\text {tabel }}$

(18.05> 2.756). Karena $t_{\text {hitung }}=18.05$ terletak di luar interval daerah penerimaan $H_{0}$, artinya $H_{0}$ ditolak yang berarti model pembelajaran TPS berpengaruh terhadap kemampuan penalaran matematika peserta didik.

Terdapat pengaruh dari setiap tahapan TPS yang memberikan siswa kesempatan berpikir secara mandiri, kemudian secara berpasangan berdiskusi untuk menyelesaikan soal menggunakan daya nalar dan kreativitas, serta mampu menyampaikan hasil yang diperolehnya dengan penuh percaya diri. Sedangkan dalam penelitian ini, selama pembelajaran model pembelajaran TPS membuat peserta didik kelas eksperimen TPS lebih aktif dalam menyelesaikan masalahmasalah yang diberikan.

Selama pembelajaran peserta didik mampu menggunakan proses berpikirnya secara individu kemudian setelah didiskusikan bersama pasangannya, peserta didik menyampaikan hasil yang peserta didik peroleh secara berani di 
depan kelas. Pada kegiatan berpasangan, peserta didik saling bertukar pikiran dan berpikir bersama untuk menentukan hasil penyelesaian. Peserta didik yang mampu memproses penyelesaian masalah secara individu kemudian dapat membagi hasil pemikirannya untuk didiskusikan kembali dengan peserta didik lain tergolong mampu menalar dengan baik, meskipun bimbingan dari pendidik sangat diperlukan. Hal ini sejalan dengan penelitian yang dilakukan oleh Ike Nataliasari Sari tahun 2014 yaitu tentang Penggunaan Model Pembelajaran Tipe Think Pair Share (TPS) untuk Meningkatkan Kemampuan Penalaran dan Pemecahan Masalah Matematis Siswa MTs.

Hipotesis yang ketiga yaitu untuk menjawab rumusan masalah manakah yang lebih efektif antara model pembelajaran GQGA dan TPS dalam meningkatkan kemampuan penalaran matematika. Karena pada uji kesamaan rata-rata sebelumnya kedua kelas memiliki perbedaan rata-rata, maka uji yang digunakan adalah uji statistik $t$ Independent Sample t-Test dan data yang dianalisis adalah data hasil nilai rentang antara pretest dan posttestkedua kelas eksperimen yang berdistribusi normal dan homogen.

Berikut tabel hasil perhitungan uji $t$ disajikan pada tabel 4. Dari rumus pada tabel 4 diperoleh hasil $t_{\text {hitung }}=-1.600$, sedangkan $t_{\text {tabel }}$ pada tingkat signifikansi $\alpha=0.05$ serta derajat kebebasan $(d k)=$ 58 diperoleh $t_{\text {tabel }}=2.001$. Hasilnya $\left|t_{\text {hitung }}\right|<t_{\text {tabel }}(1.600<2.001)$ maka $H_{0}$ diterima dan disimpulkan bahwa model pembelajaran GQGA tidak lebih efektif dari model pembelajaran TPS dalam meningkatkan kemampuan penalaran matematika peserta didik.

Selama pembelajaran di kelas GQGA, peserta didik antusias dalam mengikuti proses pembelajaran, namun dalam proses mengajukan dan menjawab pertanyaan, peserta didik cenderung hanya mengandalkan teman satu kelompoknya. Peserta didik juga belum memperlihatkan kemampuan berpikir secara maksimal ketika mengajukan pertanyaan. Sementara selama proses mengajukan dan menjawab pertanyaan, peneliti memberikan kesempatan bagi masing-masing peserta didik untuk mengemukakan pertanyaan yang benarbenar belum peserta didik pahami. Peserta didik kelas GQGA menunjukkan kemajuan dalam menggunakan proses berpikirnya dalam menjawab pertanyaan. Jawaban yang peserta didik kemukakan sudah mulai dapat peserta didik olah dan sampaikan menggunakan bahasa peserta didik sendiri. Kualitas pertanyaan yang peserta didik ajukan hanya sebatas tentang pengertian dari istilah materi yang diajarkan.

Perbedaan dengan peserta didik kelas

Tabel 4.

\begin{tabular}{lcccc}
\multicolumn{5}{c}{ Hasil Uji Hipotesis Ketiga } \\
\hline Kelas & $\begin{array}{c}\text { Jumlah } \\
\text { sampel }\end{array}$ & $\sum \boldsymbol{x}_{\boldsymbol{i}}$ & $\sum \boldsymbol{x}_{\boldsymbol{i}}^{\mathbf{2}}$ & $\begin{array}{c}\text { Rata- } \\
\text { rata }\end{array}$ \\
\hline GQGA & 30 & 1266 & 58024 & 42.2 \\
\hline TPS & 30 & 1435 & 74757 & 47.83
\end{tabular}


TPS adalah peserta didik kelas TPS lebih banyak menghabiskan waktu yang ada untuk melatih kemampuan berpikir ketika memahami masalah secara individu kemudian secara berpasangan peserta didik dapat menguatkan hasil pemikiran yang diperoleh dengan hasil temuan teman lainnya. Dengan demikian, lebih seringnya peserta didik menggunakan proses berpikirnya selama pembelajaran merupakan hal utama untuk melatih kemampuan bernalar peserta didik. Hal tersebut yang menjadikan pembelajaran dengan model GQGA tidak lebih efektif dalam meningkatkan kemampuan penalaran matematika dibanding dengan model TPS.

\section{Penutup}

Dari penelitian ini, dapat diambil kesimpulan bahwa model pembelajaran GQGA berpengaruh pada kemampuan penalaran matematika peserta didik. Keputusan tersebut diperoleh dari perhitungan uji Paired Sample t-Test yang memperoleh $t_{\text {hitung }}=18.35$. $t_{\text {hitung }}$ kemudian dibandingkan $t_{\text {tabel }}$ dengan $d k=n-1=30-1=29, \quad$ taraf signifikansi $\alpha=0.01$ diperoleh $t_{\text {tabel }}=$ 2,756. Dengan uji dua pihak diperoleh, $t_{\text {hitung }}>t_{\text {tabel }}(18.35>2,756)$. Karena $t_{\text {hitung }}=18.35$ terletak di luar interval daerah penerimaan $H_{0}$, sehingga $H_{0}$ ditolak. Maknanya, model pembelajaran GQGA memiliki pengaruh terhadap kemampuan penalaran matematika peserta didik. Selanjutnya model pembelajaran TPS berpengaruh pada kemampuan penalaran matematika peserta didik. Keputusan tersebut diperoleh dari perhitungan uji Paired Sample $t$-Test yang memperoleh $t_{\text {hitung }}=$ 18,05. $t_{\text {hitung kemudian dibandingkan }}$ $t_{\text {tabel }}$ dengan $d k=n-1=30-1=$ 29, taraf signifikansi $\alpha=0.01$ diperoleh $t_{\text {tabel }}=2,756$. Dengan uji dua pihak diperoleh, $t_{\text {hitung }}>t_{\text {tabel }}$

(18.05 > 2.756). Karena $t_{\text {hitung }}=18.05$ terletak di luar interval daerah penerimaan $H_{0}$, sehingga $H_{0}$ ditolak. Maknanya, model pembelajaran TPS memiliki pengaruh terhadap kemampuan penalaran matematika peserta didik. Selain itu, model pembelajaran GQGA tidak lebih efektif dalam meningkatkan kemampuan penalaran matematika peserta didik dibanding model pembelajaran TPS. Keputusan tersebut diperoleh dari hasil perhitungan uji Independent Sample t-Test yang memperoleh $t_{\text {hitung }}=-1.600$, sedangkan $t_{\text {tabel }}$ pada tingkat signifikansi $\alpha=0.05$ dengan derajat kebebasan $(d k)=58 \quad$ diperoleh $\quad t_{\text {tabel }}=2.001$. Hasilnya $\quad\left|t_{\text {hitung }}\right|<t_{\text {tabel }}(1.600<$ 2.001) maka $H_{0}$ diterima yang artinya Model pembelajaran GQGA tidak lebih efektif dalam meningkatkan kemampuan penalaran matematika peserta didik dibanding model pembelajaran TPS. Keputusan berikut juga dapat dilihat dari perbedaan rata-rata nilai rentang kemampuan penalaran matematika bahwa rata-rata kelas TPS lebih baik dibanding rata-rata kelas GQGA. 
Hasil penelitian ini dapat dijadikan tolak ukur bagi guru matematika untuk memilih model pembelajaran yang tepat untuk mencapai tujuan pembelajaran matematika. Melibatkan peserta didik dalam pembelajaran sangat efektif dilakukan untuk membuat peserta didik bersemangat dalam belajar. Namun, hendaknya penggunaan model pembelajaran disesuaikan dengan materi ajar dan alokasi waktu yang tersedia, karena model pembelajaran kooperatif melibatkan diskusi peserta didik dan membutuhkan waktu yang relatif lama.

\section{Daftar Pustaka}

Ahmad, H. (2015). Peningkatan Kemampuan Penalaran Matematika Materi Trigonometri Melalui Penerapan Model Pembelajaran Discovery Learning dengan Pendekatan Saintifik Pada Kelas X SMA Negeri 11 Makassar. Jurnal Daya Matematis, 3(3), 1-9.

Aisyah, E. S., \& Sofyan, D. (2014). Perbandingan Prestasi Belajar Matematika Siswa Antara Yang Mendapatkan Model Active Learning Tipe Giving Question And Getting Answer Dengan Konvensional. Jurnal Pendidikan Mosharafa, 3(1), 12-24.

Arikunto, S. (1995). Manajemen Penelitian. Jakarta: PT. Rineka Cipta.

Creswell, J. W. (2012). Educational Research Fouth Edition (Planning, Conducting and Evaluating Quantitative and Qualitative Research). Boston: Pearson Education, Inc.

Depdiknas. (2006). Permendiknas nomor 22 tahun 2006 tentang standar isi sekolah dasar (p. 2006). Jakarta: Depdiknas.

Jainuri, M. (n.d.). Materi Pertemuan Ke- 6 Instrumen dan Uji Syarat Instrumen. Retrieved from https://anzdoc.com/instrumen-danuji-syarat-instrumen.html

Nasution, Y. S., \& Surya, E. (2017). Application of TPS Type Cooperative Learning in Improving Student's Mathematics Learning Outcomes. International Journal of Science: Basic and Applied Research (IJSBAR), 34(1), 116-125.

Nataliasari, I. (2014). Penggunaan Model Pembelajaran Kooperatif Tipe Think Pair Share(TPS) untuk Meningkatkan Kemampuan Penalaran dan Pemecahan Masalah Matematis Siswa MTS. Jurnal Pendidikan Dan Keguruan, 1(1), 1-12.

Nurmanita, \& Surya, E. (2017). Membangun Kemampuan Penalaran Matematis (Reasoning Mathematics Ability) dalam Pembelajaran Matematika. Retrieved July 10, 2018, from

https://www.researchgate.net/public ation/321825158

Sari, S. P. (2013). PENGARUH PENERAPAN MODEL PEMBELAJARAN KOOPERATIPE TIPE THINK PAIR SHARE (TPS) TERHADAP HASIL BELAJAR MATEMATIKA SISWA SMP (Studi Penelitian Ekspermen di SMPN 1 Banyuresmi Garut). Jurnal Pendidikan Mosharafa, 2(1), 37-54.

Siregar, N. (2016). Meninjau Kemampuan Penalaran Matematis Siswa SMP melalui Wawancara Berbasis Tugas Geometri. Jurnal Pendidikan Mosharafa, 5(2), 128-137.

Suprijono, A. (2009). Cooperative Learning 
Teori dan Aplikasi. Kumpulan Metode Pembelajaran . 1: 88-89. (pp. 88-89).

Syartika, Y. (2016). Penerapan Model

Pembelajaran Kontekstual untuk

Meningkatkan Kemampuan

Penalaran Matematis dan Self-

Confidence Siswa. Universitas

Lampung.

Wuryani, A. (2017). Pengaruh Model

Problem Based Learning dan Problem

Posing Terhadap Kemampuan

Pemecahan Masalah Matematika

Siswa Kelas VII SMP Negeri 1

Kecamatan Balong Kabupaten

Ponorogo. Universitas

Muhammadiyah Ponorogo.

\section{Riwayat Hidup PenUlis}

\section{Asurya Octaviyunas.}

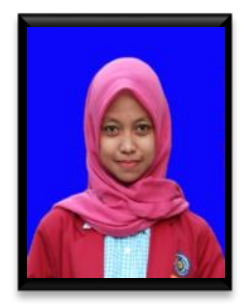

Mahasiswa S-1 Program Studi Pendidikan Matematika Universitas Muhammadiyah Ponorogo.

\section{Arta Ekayanti, S.Pd. M.Sc.}

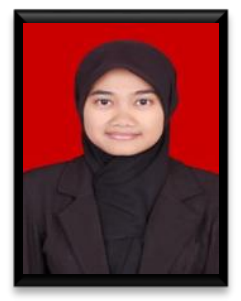

Staf Pengajar pada Program Studi S-1 Pendidikan Matematika di Universitas Muhammadiyah Ponorogo. 